\title{
Big Five Personality dengan Agresivitas Pada Remaja
}

\author{
Fitri Yolanda \\ Magister Profesi Psikologi Klinis Universitas Gunadarma, Indonesia \\ Email: fitriyolanda0301@gmail.com
}

\begin{abstract}
The purpose of this study is to learn about the differences between the five big personalities and aggressiveness in adolescents. The study was conducted with a quantitative method involving 160 adolescents, including 101 adolescent boys and 59 adolescent girls. Data analysis was performed with multiple regression to test the hypothesis in this study. From the results of the analysis found a significant effect between big five personality with aggressiveness in adolescents $(0.014,0.001,0.001)$. The higher the neuroticism, agreeableness and conscientiousness, the aggressiveness will be high, and vice versa, the lower the neuroticism, agreeableness and conscientiousness, the aggressiveness will be low, while extraversion, and openness to experience negatively correlate to aggressiveness, if the higher the extraversion and openness to experience, the aggressiveness will be low, while extraversion, and openness to experience negatively correlate to aggressiveness, low, and vice versa the lower the extraversion, and openness to experience the aggressiveness will be high.
\end{abstract}

Keywords: big five personality, aggressiveness, adolescents

\begin{abstract}
Abstrak
Tujuan penelitian ini adalah mengetahui secara empiris apakah ada pengaruh antara big five personality dengan agresivitas pada remaja. Penelitian dilakukan dengan metode kuantitatif dengan melibatkan 160 orang remaja yang diantaranya 101 orang remaja laki-laki dan 59 orang remaja perempuan. Analisis data dilakukan dengan multiple regression untuk menguji hipotesis di dalam penelitian ini. Dari hasil analisis ditemukan adanya pengaruh yang signifikan antara big five personality dengan agresivitas pada remaja $(0.014,0.001,0.001)$. Semakin tinggi neuroticism, agreeableness dan conscientiousness maka agresivitas akan tinggi, begitu juga sebaliknya semakin rendah neuroticism, agreeableness dan conscientiousness maka agresivitas akan rendah, sedangkan extraversion, dan openness to experience berkorelasi negatif terhadap agresivitas, jika semakin tinggi extraversion dan openness to experience maka agresivitas akan rendah, begitu juga sebaliknya semakin rendah extraversion, dan openness to experience maka agresivitas akan tinggi.
\end{abstract}

Kata kunci: big five personality, agresivitas, remaja

\section{Pendahuluan}

Remaja merupakan periode dari masa pubertas hingga masa dewasa. Ini merupakan suatu perkembangan yang krusial karena pada akhir periode tersebut individu tersebut harus bisa mendapatkan identitas yang tetap (Feist dan Feist, 2010). Menurut Erikson (dalam Santrock, 2007), masa remaja adalah usia dimana individu dihadapkan dengan tantangan untuk menemukan siapakah mereka, bagaimana mereka dan arah mana yang hendak ditempuh dalam kehidupan, sedangkan menurut piaget (dalam Santrok, 2007), masa remaja adalah masa individu melewati pengalaman-pengalaman konkret dan berpikir secara abstrak dan logis. Individu mulai mempersiapkan masa depan dan bangga dengan hal-hal yang dilakukan.

Masa remaja disebut juga dengan periode "Badai dan tekanan" yaitu suatu masa dimana terjadi ketegangan emosi yang tinggi dan berbuntut panjang sebuah perilaku kekerasan dikalangan remaja yang diakibatkan karena adanya perubahan fisik dan kelenjar (Hurlock, 2000). Kekerasan itu berkaitan dengan agresivitas yang berakitbat merusak dan menyakiti lawan.

Agresivitas merupakan salah satu bentuk perilaku yang dimiliki setiap orang. Myers (2010), mengatakan bahwa perilaku yang memiliki maksud untuk menyakiti seseorang baik secara fisik atau verbal. Sedangkan menurut Baron, Branscombe, dan Byrne (2009), mengatakan bahwa agresivitas adalah tindakan yang sengaja untuk menyakiti orang lain.

Perilaku agresivitas menjadi hal yang penting untuk diperhatikan umumnya bagi setiap individu dan khususnya bagi individu yaitu remaja. Fenomena kekerasan yang terjadi di Indonesia akhir-akhir ini sungguh sangat memprihatinkan. Kekerasan tersebut bersifat fisik maupun psikis, bersifat langsung maupun tidak langsung. Fenomena lainnya yang berhubungan dengan agresivitas yaitu berdasarkan Data UNICEF tahun 2016, menunjukkan bahwa kekerasan pada sesama remaja di Indonesia diperkirakan mencapai 50\%. Menurut Komisioner Bidang Pendidikan Indonesia (KPAI) pada tahun 2017-2018, angka kasus tawuran dari 12,9\% meningkat menjadi 14\%. Berita yang terbaru pada tahun 2019, beberapa kali dikejutkan dengan serangkaian berita-berita tentang kekerasan di sekolah dan geng remaja. Berita tentang siswa mem-bully guru, melawan guru dan lain-lain. Kemudian, berita tentang kasus kekerasan yang dilakukan oleh 12 orang siswi SMA 
terhadap siswi SMP di Pontianak yang bernama Audrey. Apabila masalah tersebut terus dibiarkan maka akan menimbulkan dampak yang tidak baik. Agresivitas yang dilakukan oleh anak remaja akan menjadi masalah bagi orang tua, masyarakat, pemerintah, serta remaja itu sendiri. Menurut Buss dan Perry (1992), mendefinisikan agresivitas sebagai kecenderungan untuk terlibat dalam agresi fisik dan verbal : permusuhan (hostility) dan kemarahan (anger). Menurut Buss dan Perry (1992), mengelompokkan bentuk agresi ke dalam empat bentuk agresi, yaitu agresi fisik, agresi verbal agresi dalam bentuk kebencian (hostility), dan agresi dalam bentuk kemarahan (anger).

\section{Metode Penelitian}

Penelitian ini dilakukan dengan menggunakan metode kuantitatif. Karakteristik dan subjek penelitian (n) adalah remaja sebanyak 160 orang, pada usia remaja muda atau sekitar 16-18 tahun. Subjek penelitian ditentukan dengan menggunakan teknik purposive sampling. Variable $\mathrm{Y}$ dalam penelitian ini adalah agresivitas. Skala yang digunakan adalah skala dari Budiningsih (2015).

Skala agresivitas yang dikembangkan oleh Buss dan Perry (1992) ini dibuat dari 4 dimensi yang diadaptasi dengan melakukan analisis antara faktor agresi fisik, agresi verbal, kemarahan (anger), permusuhan (hostility). Skala ini terdiri dari 24 aitem pernyataan dengan angka reliabilitas sebesar 0.771 .

Variable dalam $\mathrm{X}_{1}$ dalam penelitian ini adalah big five personality. Skala yang digunakan adalah skala dari Budiningsih (2015). Skala big five personality yang dikembangkan oleh Costa dan MacMcrae (dalam Feist dan Feist, 2010) ini dibuat dari 5 dimensi yang diadaptasi dengan melakukan analisis antara faktor neuroticism, extraversion, openness to experience, agreeableness, dan conscientiousness. Skala ini terdiri dari 50 aitem pernyataan dengan angka reliabilitas sebesar 0.774 .

Analisis uji hipotesis dilakukan dengan menggunakan analisis metode regresi berganda dengan bantuan SPSS 21.0 Statistic for Windows. Teknik analisis data regresi linier berganda merupakan suatu teknik statistik parametrik yang digunakan untuk menguji pertautan dua variabel bebas $\left(\mathrm{X}_{1}\right.$ dan $\left.\mathrm{X}_{2}\right)$ dengan variabel terikatnya (Y) (Winarsunu, 2007)

\section{Hasil dan Pembahasan}

Tabel 1. Big five personality dan agresivitas

\begin{tabular}{|c|c|c|c|c|c|}
\hline \multirow[b]{2}{*}{ Model } & \multicolumn{3}{|c|}{ Coefficients $^{\mathbf{a}}$} & \multirow[b]{2}{*}{$\mathbf{t}$} & \multirow[b]{2}{*}{ Sig. } \\
\hline & $\begin{array}{c}\text { Unstandardized } \\
\text { Coefficients } \\
\text { B }\end{array}$ & Std. Error & $\begin{array}{c}\text { Standardized } \\
\text { Coefficients } \\
\text { Beta }\end{array}$ & & \\
\hline (Constant) & 50.020 & 13.048 & & 3.834 & 000 \\
\hline Neuroticism & .501 & .201 & 188 & 2.492 & .014 \\
\hline Extraversion & -.272 & .146 & -.132 & -1.857 & .065 \\
\hline Openness & -.227 & .195 & -.084 & -1.164 & .246 \\
\hline Agreeableness & .903 & .268 & .234 & 3.374 & .001 \\
\hline Conscientiousness & -.824 & .246 & -.257 & -3.348 & .001 \\
\hline
\end{tabular}

Berdasarkan tabel 1 bahwa big five personality berpengaruh secara signifikan terhadap agresivitas pada remaja sebesar 0.000. Hasil penelitian ini sejalan dengan Denso, dkk (2006) bahwa adanya big five personality mempengaruhi agresivitas. Hasil penelitian ini sejalan dengan penelitian menurut Rahmatillah (2011) yaitu big five personality mempengaruhi agresivitas. Selain itu penelitian yang dilakukan Fauziah dan Mutia (2010) yaitu trait kepribadian big five mempengaruhi agresivitas dan penelitian Budiningsih (2015) yaitu big five personality berkorelasi positif dengan agresivitas.

Hasil penelitian ini menunjukkan big five personality berpengaruh terhadap agresivitas pada remaja bahwa neuroticism, agreeableness, dan conscientiousness sangat berperan dalam menentukan tingkah laku seseorang. Menurut McCrae dan Costa sependapat dengan Eysenck (dalam Feist dan Feist, 2010), bahwa sifat dari kepribadian adalah bipolar dan mengikuti distribusi lonceng, yaitu kebanyakan individu memiliki skor yang berada dekat dengan titik tengah dari setiap sifat dan hanya sedikit individu yang memiliki skor pada titik ekstrem. Dalam buku kepribadian (Feist dan Feist, 2010), mengatakan bahwa pola-pola dari sifat yang relatif permanen dan memiliki karakter unik secara konsisten dan yang pada akhirnya memunculkan perilaku individu. Kepribadian yang relatif menetap cenderung mendorong seseorang untuk berperilaku sesuai dengan tujuan dan tuntutan yang diberikan terhadap seseorang. Berdasarkan penuturan tersebut jika neuroticism, 
agreeableness, dan conscientiousness pada remaja tinggi maka perilaku agresivitas akan terlihat rendah sehingga secara tidak langsung perilaku baik didalam diri individu akan muncul dengan sendirinya.

Dalam big five personality selain dapat meningkatkan agresivitas yang sejalan dengan teori Larsen dan Buss (2010), kepribadian merupakan sekumpulan trait dan mekanisme psikologis didalam diri individu yang terorganisir dan relatif bertahan dan mempengaruhi interaksi serta adaptasi, intrapsikis, fisik dan lingkungan sosial. Kepribadian seseorang mempengaruhi cara individu dalam bereaksi, berpikir, merasa, berinteraksi, dan beradaptasi dengan orang lain, termasuk dalam perilaku agresif. Dengan berperilaku demikian menunjukkan bahwa adanya pengaruh kepribadian big five terhadap agresivitas pada remaja.

Nilai koefisien regresi antara neuroticism dengan agresivitas remaja sebesar 0.188 . Hal ini menunjukkan bahwa neuroticism memiliki hubungan yang positif. Neuroticism merupakan salah satu faktor yang berpengaruh signifikan terhadap agresivitas pada remaja sebesar 0.014. Dapat disimpulkan bahwa semakin tinggi neuroticism dalam diri individu maka akan semakin tinggi tingkat agresivitas pada individu, begitu juga sebaliknya semakin rendah neuroticism dalam diri individu maka akan semakin rendah tingkat agresivitas pada individu. Hal ini sesuai dengan penelitian yang dilakukan oleh McCrae dan Costa (dalam Feist dan Feist, 2010) bahwa individu yang memiliki neuroticism yang tinggi maka cenderung untuk cemas, temperamental, sensitif, emosional dan rentan terhadap gangguan yang berhubungan dengan stress, begitu juga sebaliknya individu yang memiliki neuroticism rendah maka akan cenderung tenang, tidak tempramental, puas terhadap diri diri sendiri dan tidak emosional.

Nilai koefisien regresi antara agreeableness dengan agresivitas remaja sebesar 0.234. Hal ini menunjukkan bahwa agreeablenes memiliki hubungan yang positif. Agreeableness merupakan salah satu faktor yang berpengaruh signifikan terhadap agresivitas pada remaja sebesar 0.001. Dapat disimpulkan bahwa semakin rendah agreeablenes pada individu maka akan semakin tinggi tingkat agresivitas pada individu, begitu juga sebaliknya semakin tinggi agreeableness pada individu maka akan semakin tinggi tingkat agresivitas pada individu. Hal ini sesuai dengan penelitian yang dilakukan oleh McCrae dan Costa (dalam Feist dan Feist, 2010) antara individu yang berhati lembut dengan yang kejam. Individu yang memiliki agreeableness tinggi cenderung mudah percaya, rendah hati, suka mengalah, mudah menerima dan memiliki perilaku yang baik, begitu juga sebaliknya individu yang memiliki agreeableness rendah cenderung pelit, tidak ramah, mudah kesal, senang mengkritik orang lain dan penuh curiga.

Nilai koefisien regresi antara conscientiousness dengan agresivitas remaja sebesar -257. Hal ini menunjukkan bahwa conscientiousness memiliki hubungan yang negatif. Conscientiousness merupakan salah satu faktor yang berpengaruh signifikan terhadap agresivitas pada remaja sebesar 0.001. Dapat disimpulkan bahwa semakin rendah conscientiousness pada individu maka akan semakin tinggi tingkat agresivitas pada individu, begitu juga sebaliknya semakin tinggi conscientiousness pada individu maka akan semakin rendah tingkat agresivitas pada individu. Hal ini sesuai dengan penelitian yang dilakukan oleh McCrae dan Costa (dalam Feist dan Feist, 2010) bahwa individu yang memiliki conscientiousness rendah merupakan individu yang cenderung memiliki pikiran yang kacau, ceroboh, pemalas, tidak memiliki tujuan, dan lebih memilih menyerah saat mengalami kesulitan pada saat mengerjakan sesuatu, begitu juga sebaliknya individu yang memiliki conscientiousness tinggi maka cenderung untuk bekerja keras, terarut, terkontrol, teroganisasi, ambisius, fokus pada pencapaian dan disiplin.

Nilai koefisien regresi antara extraversion dengan agresivitas remaja sebesar -132. Hal ini menunjukkan bahwa extraversion memiliki hubungan yang negatif. Extraversion merupakan salah satu faktor yang tidak berpengaruh signifikan terhadap agresivitas pada remaja sebesar 0.065. Dapat disimpulkan bahwa semakin tinggi extraversion pada individu maka akan semakin rendah tingkat agresivitas pada individu, begitu juga sebaliknya semakin rendah extraversion pada individu maka akan semakin tinggi tingkat agresivitas pada individu. Hal ini sesuai dengan penelitian yang dilakukan oleh McCrae dan Costa (dalam Feist dan Feist, 2010) bahwa individu yang memiliki extraversion tinggi cenderung penuh kasih sayang, ceria, senang berbicara, senang berkumpul dan menyenangkan, begitu juga sebaliknya individu yang memiliki extraversion rendah biasanya tertutup, pendiam, penyendiri, pasif, dan tidak mempunyai cukup kemampuan untuk mengekspresikan emosi yang kuat.

Nilai koefisien regresi antara openness to experience dengan agresivitas remaja sebesar -084. Hal ini menunjukkan bahwa openness to experience memiliki hubungan yang negatif. Openness to experience merupakan salah satu faktor yang tidak berpengaruh signifikan terhadap agresivitas pada remaja sebesar 0.246. Dapat disimpulkan bahwa semakin tinggi openness to experience pada individu maka akan semakin rendah tingkat agresivitas pada individu, begitu juga sebaliknya semakin rendah openness to experience pada individu maka akan semakin tinggi tingkat agresivitas pada individu. Hal ini sesuai dengan penelitian yang dilakukan 
oleh McCrae dan Costa (dalam Feist dan Feist, 2010) bahwa individu yang memiliki openness to experience tinggi cenderung kreatif, imajinatif, penuh rasa penasaran dan memiliki variasi, begitu juga sebaliknya individu yang memiliki openness to experience tinggi rendah biasanya cenderung rendah hati, konservatif, konvensional dan tidak terlalu penasaran terhadap sesuatu

\section{Kesimpulan}

Dari penelitian ini dapat diketahui mengenai pengaruh big five personality dengan agresivitas pada remaja. Dalam penelitian ini peneliti hanya meneliti faktor-faktor yang dapat mempengaruhi agresivitas pada remaja seperti neuroticism, agreeableness dan conscientiousness, sedangkan extraversion, dan openness to experience berkorelasi negatif terhadap agresivitas. Walaupun faktor-faktor big five personality dapat mempengaruhi agresivitas pada remaja, tidak bisa dilupakan bahwa ada faktor-faktor lain yang juga memiliki peran penting dari perkembangan agresivitas pada remaja.

Saran peneliti berikan untuk penelitian selanjutnya meneliti atau menganalisa variabel-variabel lain yang dapat mempengaruhi agresivitas seperti kecerdasan emosional, self control dan pola asuh. Kedua, mengkondisikan subjek dengan suasana yang nyaman pada saat mengisi kuesioner agar tidak terburu-buru. Ketiga, umumnya dan khususnya untuk subjek penelitian harus lebih dapat mengenali diri sendiri dan memperkuat hal-hal positif yang ada pada dirinya agar hal-hal negatif seperti perilaku agresi dapat berkurang, yaitu dengan mendekatkan diri pada tuhan, mengurangi menonton film-film yang menyajikan tentang kekerasan dapat menimbulkan agresi pada individu, menjauhi pergaulan yang buruk. Keempat, orangtua disarankan dapat memberikan perhatian khusus kepada anak mereka masing-masing sehingga mereka merasa masih diperhatikan. Orangtua di rumah bisa memberikan tanggung kepada anaknya di rumah maupun di luar rumah sehingga mereka merasa dibutuhkan. Selain itu juga diharapkan untuk orangtua lebih memberikan kepercayaan atau trust kepada anakanaknya agar ketika mereka berhadapan dengan dunia luar tidak mengalami kecemasan dan rentan terhadap stres.

\section{Daftar Rujukan}

Alwisol. (2007). Psikologi kepribadian. Malang : Penerbitan Universitas Muhammadiyah

Anderson, C. A., \& Bushman, B. J. (2002). Human aggression. Iowa State University.

Anderson, C. A., \& Bushman, B. J. (2002). The sage handbook of social psychology. Thousand Oaks, C. A : Sage publications, Inc.

Anwar, Ali. (2018). KPAI tawuran pelajar 2018 lebih tinggi dibandingkan tahun lalu. Retrieved from http://metro.tempo.co/read/1125876/kpai-tawuran-pelajar-2018-lebih-tinggi-dibandingtahunlalu/full\&view=ok. On february 27, 2019.

Anwar, Ali. (2019). Bacok lawan tawuran hingga tewas 7 remaja tangerang ditangkap. Retrieved from http://metro.tempo.co/read/1198513/bacok-lawan-tawuran-hingga-tewas-7-remaja-tangerang-ditangkap. On february 27, 2019.

Baron, R. A., Branscombe, N.R \& Byrne, D. (2009). Social Psychology. United States of Amerika.

Budinigsih, Nuraini. (2015). Pengaruh big five personality dan religiusitas terhadap agresivitas pada santriwan dan santriwati SMA La Tansa Banten. Skripsi (tidak diterbitkan). Jakarta : Fakultas Psikologi UIN Syarif Hidayatul Jakarta.

Buss, D. M., \& Larsen, R. J. (2010). Personality Psychology : domain of knowledge about human nature, (4th edition). New York : McGraw-Hill.

Buss, A. H., \& Perry, M. P. (1992). The aggression questionnaire. Journal of Personality and Social Psychology, (63), 452-459.

Corey, Gerald. (2009). Teori dan praktek konseling dan psikoterapi. Bandung : PT Refika Aditama.

Costa, P. T., Jr. \& McCrae, R. R. (1992). Revised neo personality inventory (NEOPI-R) and neo five-factor inventory (NEOFFI) professional manual. Odessa, FL : Psychological Assessment Resources.

Denson, Thomas F., et al. (2006). The displaced aggression questionnaire. Journal of personality and social psychology, (90). 6. doi : 1032.

Fauziah, S \& Mutiah, D. (2013). Pengaruh trait kepribadian big five dan konformitas teman sebaya terhadap agresivitas anak punk di jabodetabek. Jurnal Psikologi UIN Syarif Hidayatul Jakarta.

Feist, J., \& Feist, G. J. (2010). Teori kepribadian “Theories of Personality” (Jilid Dua). Jakarta : Salemba Humanika.

Hendri, Dedi. (2019). 202 anak tawuran dalam dua tahun. Retrieved from http://www.kpai.go.id/berita/kpai-202anak-tawuran-dalam-dua-tahun. On february 27, 2019.

Hurlock, Elizabeth B. (2000). Psikologi perkembangan suatu pendekatan sepanjang rentang kehidupan. Jakarta : Erlangga.

Kamus Besar Bahasa Indonesia. Jakarta : PT Gramedia Pustaka Utama. 
Ingarianti, T. M. (2014). Hubungan antara kepribadian "The big five personality" dengan organizational citizenship behavior pada karyawan. Skripsi (tidak diterbitkan). Malang : Fakultas Psikologi Universitas Muhammadiyah Malang.

Iro \& Wiwin. (2018). Kekerasan remaja Indonesia mencapai 50 persen. Retrieved from http://fk.ugm.ac.id/kekerasan-remaja-indonesia-mencapai-50-persen/. On February 27, 2019.

Melawati, Lia. (2014). Hubungan antara kepribadian big five dengan perilaku Agresi pada anggota TNI batalyon infanteri 301/ prabu Kiansantang (yonif 301/pks). Jurnal Pustaka Universitas Padjadjaran.McCrae \& John. (1992). An introduction to the five factor model \& it's applications. Journal of personality, volume (60). Issue 2.

Putra, Ade. (2019). Fakta dibalik tegar justice for Audrey siswi SMP korban bully yang trending topic dubua. Retrieved fom http://news.okezone.com/read/2019/04/10/340/2041394/fakta-di-balik-tagar-justice-for audrey-siswi-smp-korban-bully-yang-trending-topic-dunia. On february 27, 2019.

Rahmatillah, A. (2011). Pengaruh tipe kepribadian big five dan self-control terhadap agresivitas satuan polisi pamong praja kota tangerang. Skripsi (tidak diterbitkan). Jakarta : Fakultas Psikologi UIN Syarif Hidayatul Jakarta.

Rosito, A Christina. (2018). Eksplorasi tipe kepribadian big five personality traits dan pengaruhnya terhadap prestasi akademik. Jurnal psikologi pendidikan dan konseling : jurnal kajian psikologi pendidikan dan bimbingan konseling, 4 (2), 6-13. doi : http://dx.doi.org/10.26858/jpkk.v4i1.3250.

Santrock, J.W. (2007). Adolescence remaja. Jakarta : Penerbit Erlangga

Santoso. (2019). Justice for Audrey viral siswi SMP yang dikeroyok belasan siswi SMA di Pontianak. Retrieved from https://news.detik.com/berita/4502768/justiceforaudrey-viral-siswi-smp-keroyok-belasan-siswi-smapontianak. On february 27, 2019.

Sarwono, Sarlito W. 2009. Psikologi sosial. Jakarta: Salemba Humanika.

Shepherd, H. J., \& Lack, C.W. (2009). Relationship of personality traits to social aggression in college females. Sugiyono. (2013). Metode penelitian kuantitatif kualitatif dan R\&D. Bandung : Alfabeta.

Sulistiyo, C. F. (2016). Hubungan antara kontrol diri dengan perilaku agresif dalam berkendara pada komunitas motor di kota Surakarta. Skripsi (tidak diterbitkan). Fakultas Psikologi muhammadiyah Surakarta. 